which are summarized in this report, were published in a report, "Conservation in Micronesia", compiled by $H$. J. Coolidge, and they were transmitted to the Navy Department and the administrative authorities of the Trust Territory of the Pacific Islands. Later, the Pacific Science Board was requested to nominate a candidate for the post of conservation officer, and to organise an advisory committee. This has been done in two panels, one in Washington, D.C., and one in Honolulu.

The meeting on June 19, 1948, of the United States Committee on the Oceanography of the Pacific was concerned with the presentation at the Seventh Pacific Science Congress of the American contribution in this field. Reference is also made to the progress of the Pacific Oceanic Biology project, but while the report lists the American men of science who attended the Seventh Pacific Science Congress, a full account of that Congress is promised in the 1949 report of the Board. Among the advisory activities of the Board in 1948, the report stresses the close association of the Board with the Fulbright programme of the international exchange of personnel of the Conference Board of Associated Research Councils.

A total of 43,300,000 dollars was announced for research in the Pacific area, including five million for Australia, seven million for Netherlands East Indies, twenty million for China and 2,300,000 dollars for New Zealand, and some of the twenty million dollars announced for the United Kingdom and the five millions for France may be available for their Pacific Colonies. The Board was also consulted on matters concerning the scientific personnel and programme of the Research Cauncil of the South Pacific Commission, and the executive secretary of the Board, as one of the two United States Government delegates to the Fontainebleau Conference, assisted in the establishment of the new International Union for the Protection of Nature.

\section{LADY TATA MEMORIAL TRUST}

$\mathrm{T}$

HE Lady Tata Memorial Trust, founded in 1932 by the late Sir Dorabji Jamsetji Tata, of Bombay, in memory of his wife, the late Lady Tata, has pub. lished a report of the work done by its international section during the past fifteen years*. In this report is set out a summary of the work on leukrmia and other blood diseases which has been financially helped by the Trust during this period on the recom. mendation of its distinguished European scientific advisory committee.

About one-fifth of the income of the Trust is devoted each year to scholarships and prizes, which arelawarded to Indian workers for research by them on any problem related to human suffering; the other four-fifths provides grants or scholarships which are open to persons of any nationality in any country for work on diseases of the blood, with special reference to leukæmia. The report shows that some twenty-nine workers in eleven different countries have been helped by the Trust, either by short-term grants or scholarships or by expenses grants for long-term programmes of work on the leukæmias at recognized centres. These long-term programmes have been assisted at the Department of Pathology, Cornell University Medical College, New York, under Prof. E. L. Opie and Prof. Jacob Furth; at the

* Report on the Working of the Lady Tata Memorial Trust

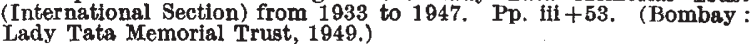

Institut du Cancer, Paris, under Prof. G. Roussy ; and at the University of Copenhagen, under the late Prof. Oluf Thomsen and latterly under Prof. J. Engelbreth-Holm.

These long-term studies are summarized in this report, and Prof. Furth gives a valuable brief summary of our present knowledge of the leukæmias. Leukæmia behaves, he writes, as a neoplastic disease, and the availability of leukæmic animals in large numbers has made it possible to prove that leukæmia is "cancer of the blood-forming cells". Leukæmic cells are, however, not inherited as such, even by the mice of the leukæmic strain $A k$, most members of which will die of leukæmia at the age of 7-11 months. At a fow sites in the body, of which the lymphoid tissue in and around the thymus gland is one, normal cells become leukæmic a few weeks before signs of leukæmia are noted. These sites are determined largely by heredity, and there is evidence that the change is analogous to a somatic mutation. There is no evidence that the leukæmic change can be prevented, and the trend towards an increase in the incidence of leukæmia is likely to remain.

It has been known for some time that a virus-like agent causes leukæmia in fowls, and this, together with leukæmia in the rat, has been studied by Prof. Roussy and his colleagues. Prof. Roussy concludes that the same virus may cause either transmissible leukæmia or sarcoma of fowls; that considerable active immunization against fowl leukæmia is possible; that fowl leukæmia can occasionally be induced by carcinogenic hydrocarbons; and that the transplantable chloroma found in the rat has close affinities to human chloroma.

At the University of Copenhagen, Prof. EngelbrethHolm and his colleagues have studied leukæmia of fowls and mice. They agree that fowl leukæmia is a true malignant tumour and that different types of fowl leukæmia can be produced by the same virus. This virus can also induce sarcoma. Their attempts to treat the disease by X-rays, hormones and chemotherapy failed, but a strong immunity could be produced in chicks by virus adsorbed to aluminium hydroxide. In ducks a powerful immune serum was produced by injection of blood from leukæmic fowls. Leukæmia in mice was accelerated by treatment with carcinogenic agents (X-rays, hydrocarbons), and the implications of this are discussed. Prof. Engelbreth. Holm's book, "Spontaneous and Experimental Leukæmia in Animals" (Edinburgh and London: Oliver and Boyd, Ltd., 1942) was written at the request of the scientific advisory committee of the Trust; it was smuggled out of Denmark during the earliest period of the German occupation and was then published under the authority of the Trust.

Workers helped by the Trust have studied karyoclastic drugs, such as urethane and nitrogen mustards, and have played their part in the development of folic acid and in work with radioactive isotopes, which can be used for the induction and treatment of leukæmia. Demographic studies of the disease, too, have been aided by the Trust, which has also helped to establish the.Oxford Lymph-Node Registry. One has only to look through the list of grants given, in this report to realize how broad and wise is the outlook" of the scientific advisory committee. The help given has not been confined to the study of leukæmia, but has also included grants for work on the megaloblastic anæmias, tropical nutritional anæmia, the argentaffin cells of the alimentary tract and the effects of pterins on blood-formation.
G. LAPAgE 